\title{
Effectiveness of Macroinvertebrate Species to Discern Pollution Levels in Aquatic Environment
}

\author{
Julius D. Elias \\ Tanzania Industrial Research and Development Organization (TIRDO), Dar es Salaam, Tanzania \\ Email: julius.zeanimo@gmail.com,animoj@yahoo.com,julius.elias@tirdo.or.tz
}

How to cite this paper: Elias, J.D. (2021) Effectiveness of Macroinvertebrate Species to Discern Pollution Levels in Aquatic Environment. Open Journal of Ecology, 11, 357-373.

https://doi.org/10.4236/oje.2021.114025

Received: February 7, 2021

Accepted: April 22, 2021

Published: April 25, 2021

Copyright $\odot 2021$ by author(s) and Scientific Research Publishing Inc. This work is licensed under the Creative Commons Attribution International License (CC BY 4.0).

http://creativecommons.org/licenses/by/4.0/

(c) (i) Open Access

\begin{abstract}
The World is transforming more rapidly than ever before as a result of urbanization and industrialization. Such unrelenting destruction of nature has surpassed the capacity of mother Earth to support the aquatic ecosystem. Apart from freshwater macroinvertebrate species, there is no single measure of declining freshwater ecosystem that can capture either the short and long-term changes or the trend of overall freshwater ecosystem health. In that regard, the macroinvertebrates and physico-chemical variables were used as surrogates to determine levels of impairment within and between Pangani and Wami-Ruvu rivers' basins in Tanzania. Spatial distribution of macroinvertebrate communities in the basins is significantly influenced by varying levels of environmental variables as a result of geomorphology and improper land uses. Principal Components Analysis (PCA) ordination showed two distinct patterns of biometrics that clearly discriminate reference sites from monitoring sites at each basin and consequently demonstrate the differences in water quality and physical habitat between the site categories. Similarly, distinctive macroinvertebrate species were observed and varied considerably among the site categories in the studied rivers as a function of tolerance levels. Impacted sites are characterized by either absence of any sensitive taxa or presence of few if any; greater dominance of only a few taxa that are tolerant to pollution. Therefore, the more diverse orders with a wider range of occurrences and tolerance to pollution (Ephemeroptera (E), Diptera (D), Odonata (O) and Trichoptera (T)) can be considered as potential bio-indicators in developing biomonitoring index for Tropical African Rivers as they showed a significant discriminating power that separated reference from monitoring sites.
\end{abstract}

\section{Keywords}

Macro-Invertebrate, Biomonitoring, Bio-Indicator, Freshwater, Pollution and Tolerance 


\section{Introduction}

Tropical African rivers are subject to the most pressing requirements for improved attention to sustainable use due to the rapidly increasing anthropogenic pressure that threatens their ecological and socio-economic values [1] [2] [3] [4]. Freshwater macroinvertebrate species are at a high risk of extinction due to habitat degradation following overwhelming human activities (i.e. invasive industrialization, agriculture, and urban development) near rivers [4]-[9]. It is unlikely that there is a substantial number of freshwater bodies remaining that have not been irreversibly altered from their original state as a result of anthropogenic activities [10].

Improper land uses near rivers have caused significant changes in the flow regimes of rivers while altering negative impacts on the environment and loss of ecosystem functioning [8] [11]. The presence of human induced stressors (such as pollution, habitat destruction, and hydrological alterations) can directly impact freshwater habitat by significantly changing the biotic integrity and functional ability of a vast number of riverine ecosystems [12] [13]. In Tanzania, for example, Themi (near Arusha town), Karanga, Njoro and Rau (near Moshi town in Kilimanjaro) and Mzinga, Msimbazi, Yombo, and Kizinga (in Dar es Salaam) rivers were all found to be polluted by urban-based industrial and domestic wastes [6] [14] [15] [16]. Similarly, human induced activities (such as pollution, habitat transformation of landscape and hydrological alterations) have direct impacts on freshwater habitat as they significantly change biotic integrity and functional ability of many river ecosystems worldwide, particularly in urban and agricultural areas [8] [12] [13].

This is due to the fact that macro-invertebrate communities play the role of transforming organic inputs and as indicators of the quality, structural and functioning of aquatic environment. Apart from macroinvertebrates, there is no single measure of declining freshwater ecosystem that can capture either the short and long term changes or the trend of overall freshwater ecosystem health. In that regard, this study was designed to examine the correlation of macroinvertebrates with environmental variables and reveal their ability to discern reference sites from monitoring sites. Moreover, legislations should set ecological standards and quality objectives and make bio-monitoring programmes of aquatic ecosystems mandatory.

\section{Materials and Methods}

\subsection{Description of Study Areas}

Eighty-five (85) sampling sites of varying degradation levels along Pangani and Wami-Ruvu river basins were selected for sampling to ensure the characterization of macro-invertebrates and determination of physico-chemical parameters. The basins provide a wide range of riverine systems, climate, geology, topography and human disturbance within different hydrological patterns. Pangani river basin is located in the north-east of Tanzania mainland, $36^{\circ} 23^{\prime} \mathrm{E}-39^{\circ} 13^{\prime} \mathrm{E}$ and 
$03^{\circ} 03^{\prime} \mathrm{S}-05^{\circ} 59^{\prime} \mathrm{S}$ with an altitude ranging from $0-4500 \mathrm{~m}$. The basin has an estimated area of about $43,650 \mathrm{~km}^{2}$ that covers 14 districts and two municipalities of Arusha (2369.76 km²), Manyara (17,911.35 km²), Kilimanjaro (10,346.76 km²), and Tanga $\left(10,223.17 \mathrm{~km}^{2}\right)$ regions together with $3900 \mathrm{~km}^{2}$, in the southern part of Kenya. Land-use systems and practices along Pangani basin range from small-scale farming to large-scale mechanized agriculture, overexploitation of riparian vegetation, construction of dam and hydro power projects, grazing, bathing and washing, dumping of industrial and domestic wastes and human settlement.

The Wami-Ruvu river basin is elongated and extends from the central part of Tanzania towards the eastern part between $36^{\circ} 00^{\prime} \mathrm{E}-39^{\circ} 00^{\prime} \mathrm{E}$ and $05^{\circ} 00^{\prime} \mathrm{S}$ $07^{\circ} 00^{\prime} \mathrm{S}$ with an altitude of $0-2500 \mathrm{~m}$ before draining into the Indian Ocean at Saadani village. It extends through Dodoma, Morogoro, Coast and Dar es Salaam regions covering a total area of $72,930 \mathrm{~km}^{2}$ of wide plains and mountain ranges.

The two basins experience equatorial type of climate with mean annual rainfall between 1100 and $3000 \mathrm{~mm}$ per annum, with a maximum mean temperature ranging from $32^{\circ} \mathrm{C}-35^{\circ} \mathrm{C}$ in the dry season and lowest of $14^{\circ} \mathrm{C}-18^{\circ} \mathrm{C}$ during the wet season. Human activities that are impacting the Wami-Ruvu River basins include mining activities, brick making, poor agricultural practices involving application of agrochemicals, saline water intrusion, uncontrolled and illegal water abstraction for irrigation, bathing and washing along river basins, fauna droppings and disposal of untreated industrial and domestic wastes into the two rivers.

\subsection{Sampling Design}

The two river basins were divided into two site categories in which 39 reference (least impacted) and 46 monitoring (highly impacted) sites were established. Triplicate water and macro-invertebrate assemblage samples were collected at each site near the end of dry and wet seasons to capture the effect of respective seasons. The sampling sites were selected based on their ease of accessibility, presence and or absence of sustained anthropogenic disturbances, pools, riffles and runs, and degree of water physico-chemical and habitat degradation.

\subsubsection{Physico-Chemical Data Collection}

Water physico-chemical i.e., $\mathrm{pH}$, dissolved oxygen (DO), temperature, turbidity, conductivity, total dissolved solids (TDS), ammonia $\left(\mathrm{NH}_{4}^{+}-\mathrm{N}\right)$, potassium $\left(\mathrm{K}^{+}\right)$, sulphate $\left(\mathrm{SO}_{4}^{2-}\right)$, soluble reactive phosphorous ( $\mathrm{SRP}\left(\mathrm{PO}_{4}^{3-}-\mathrm{P}\right)$, nitrate $\left(\mathrm{NO}_{3}^{-}-\mathrm{N}\right)$ and nitrite $\left(\mathrm{NO}_{2}^{-}-\mathrm{N}\right)$ plus Biological Oxygen Demand (BOD) and Chemical Oxygen Demand (COD) were measured. Water temperature, conductivity, DO, TDS, and $\mathrm{pH}$ were measured and recorded in situ at each site using a multi-sensor probe YSI Professional Plus Water Quality Instrument (Model 605,0000) while turbidity was measured using a turbidity meter. Laboratory analysis for water chemistry variables involved filtering of collected water samples using $0.45 \mu \mathrm{m}$ glass fiber filters and placed in hydrochloric acid washed polythene bottles before being preserved 
in a cool box at about $\leq 10^{\circ} \mathrm{C}$. The samples were then taken to the Department of Aquatic Sciences and Fisheries Laboratory of the University of Dar es Salaam for analysis.

Nitrate $\left(\mathrm{NO}_{3}^{-}-\mathrm{N}\right)$, nitrite $\left(\mathrm{NO}_{2}^{-}-\mathrm{N}\right)$, ammonia $\left(\mathrm{NH}_{4}^{+}-\mathrm{N}\right)$ and SRP $\left(\mathrm{PO}_{4}^{3-}-\mathrm{P}\right)$ were analyzed using standard spectrophotometric methods described in APHA [17] [18]. Ammonia was determined using a Phenate method, nitrate and nitrite concentrations by Cadmium reduction method, SRP analyzed using molybdate ascorbic acid method, $\mathrm{SO}_{4}^{2-}$ by turbid-metric method, $\mathrm{BOD}$ by instrumental (BOD track) method and COD using Instrumental (semi-automated calorimetry) method [18] [19].

\subsubsection{Macro-Invertebrate Samples}

Macro-invertebrate samples were collected at the end of wet and dry seasons to capture the effect of respective seasons. Samples were collected throughout each sampling reach of $100 \mathrm{~m}$ by the same operator using a $30 \times 30 \mathrm{~cm}$ kick-net with a $250 \mu \mathrm{m}$ mesh size according to the Barbour et al. [20] method. To avoid bias due to spatial variations or patchiness, samples were collected in triplicates and at random locations within $200 \mathrm{~m}$ reach, making nine samples per reach or sampling site. The nine individual samples were pooled together as one composite sample was sorted grossly in the field at order level before preservation in $10 \%$ formaldehyde solution prior to transportation to the laboratory for identification [21]. In the laboratory, macro-invertebrate specimens were identified to the lowest possible taxonomic level) under the help of dissecting microscope (100x magnification) according to the method of Merritt and Cummins [22] and Thorp and Covich [23] in relation to the local conditions, followed by listing and counting of individuals.

\subsubsection{B-IBI Scores}

Percentages of 14 metrics including H-FBI [24] were used to calculate Benthic Index of Biological Integrity (B-IBI) at each site according to Barbour et al. [20], with their abundances being excluded. These include: \% Ephemeroptera, \% Plecoptera, \% Trichoptera, \% Baetidae, \% Odonata, \% Dominant taxa, \% Taxa richness, \% EPT, \% H-FBI, \% Diptera, \% Chironomidae and \% Oligochaeta, \% Non-insect taxa, and Shannon Diversity Index.

Metrics were standardized into three score ranges based on the degree of impairment. Maximum score of 5 was assigned to little impaired sites, 3 for moderately impaired sites, and 1 for severely impaired sites. These scores are simply arbitrary standards according to Karr and Chu [1]. Standardized metric scores were then added to produce the B-IBI score on a 70-point scale (involving 14 characters each with a maximal score of 5) and 14-point score (involving 14 characters with minimal value of 1 ). The B-IBI values were then standardized to a 100-point scale: giving 68 to 100 (little impaired), 46 to 67 (moderately impaired), 20 to 45 (highly impaired) and 0 to 19 (severely impaired) as shown in Table 1 based on actual rating criteria prescribed by Pond et al. [25] and Arslan et al. 
Table 1. Classification of water quality status based on impairment levels from B-IBI score data.

\begin{tabular}{ccc}
\hline B-IBI score & Water quality characterization & Impairment level \\
\hline 0 to 19 & Very Poor water quality & Severely impaired \\
20 to 45 & Poor water quality & Highly impaired \\
46 to 67 & Fair water quality & Moderately impaired \\
68 to 100 & Good water quality & Little impaired \\
\hline
\end{tabular}

[26]. For the purpose of this study, streams/rivers B-IBI values below a score of 68 would be impaired (i.e., fair, poor and very poor).

\section{Statistical Analyses}

MS Excel, Community Analysis Package version 4 (CAP IV), Species Richness and Diversity IV (SDR IV), and Instat ${ }^{\circledR}$ version $3\left(\mathrm{GraphPad}^{\circledR}\right)$ softwares were used to analyze the data. All data were organized using MS Excel spreadsheet and saved in appropriate format acceptable by particular software. Any variable that failed the normality test was transformed (to either $\log (\mathrm{x}+1)$, square root, or arcsine), where appropriate. Species diversity and species accumulative curves were performed by Species Richness and Diversity IV (SDR IV) software [27]. Significance tests were performed by one-way analysis of variance (ANOVA) followed by the post hoc Tukey's multiple comparisons test, with $\mathrm{p}$ set at 0.05 to determine the differences between and within the site categories based on their mean biotic and abiotic data. Relationships between and within site categories of the two basins were calculated using Instat ${ }^{\circledR}$ version $3\left(\mathrm{GraphPad}^{\circledR}\right)$ and Community Analysis Package version 4 (CAP IV) software [28].

\section{Results}

\subsection{Macro-Invertebrate Assemblages}

A combined list of 12,629 macro-invertebrates' communities representing 79 families of 17 orders collected from Pangani and Wami-Ruvu basins during the rainy and dry seasons is abridged in Appendix 1. Of that total, $60.95 \%(\mathrm{~N}=12,629)$ was observed at Pangani that dominated with dipterans versus $39.05 \%$ of Wami-Ruvu basin under the dominance of ephemeropterans. Collectively, dipterans and ephemeropterans represented $97.39 \%$ and $48.82 \%$ of the observed organisms along Pangani and Wami-Ruvu basins, respectively. Trichoptera was the most diverse order, found with 11 families, followed by Ephemeroptera, Diptera, and Odonata, with 10 families each. Hydroida, Lepidoptera, Plecoptera, Tubicifida and Turbellaria were the least diverse orders, each being represented by one family. The remaining orders had intermediate numbers of families that were rather uniform among sites, ranging from 2 to 9 . Besides, 19 rare families (with abundances $\leq 0.3 \%$ in all site categories) were registered at Pangani compared to 15 of Wami-Ruvu basin and the absence of Nepidae, Notonectidae and Lumnichidae fami- 
lies. Ephemeropterans and trichopterans were observed at all reference sites (regardless of the seasonality) and in monitoring sites during the wet season as opposed to dipterans and Odonata.

Approximately 15 metrics were calculated separately to characterize macroinvertebrate assemblages for Pangani and Wami-Ruvu data. These metrics were categorized according to their taxonomical and ecological characteristics. These include: B-IBI, \%EPT, H-FBI, percentages of Ephemeroptera, Trichoptera, Baetidae, Plecoptera, Oligochaeta, Chironomidae, Odonata, Diptera, Dominant Taxa, SDI, Non-Insecta and Relative Taxa Richness. Reference sites found dominated by percentages of Baetidae, Ephemeroptera, Trichoptera, Plecoptera, and B-IBI scores while Odonata, Diptera, Oligochaeta, and Chironomidae dominated the monitoring sites (Table 2). However, the low value of B-IBI scores and \% EPT and higher $\mathrm{H}-\mathrm{FBI}$ could be taken as an indicator of degraded water quality within a basin.

\subsection{Physico-Chemical Parameters}

Generally, higher mean values of recorded physico-chemical variables followed the order: TDS $>$ COD $>$ BOD $>$ Temperature $>$ Conductivity and TDS $>$ COD $>$ $\mathrm{BOD}>\mathrm{SO}_{4}^{2-}>$ Turbidity at Pangani and Wami-Ruvu, respectively. However, there was also a trend for most variables being higher at monitoring sites relative to reference sites. For instance, $\mathrm{SO}_{4}^{2-}, \mathrm{K}^{+}, \mathrm{NH}_{4}^{+}-\mathrm{N}$, Conductivity, and BOD were $45,40,15,8$ and 6 times higher, respectively at Wami-Ruvu monitoring sites while, TDS and COD were 38 and 5 times higher at Pangani monitoring sites compared to reference sites. Moreover, mean DO was higher at all reference sites and there was no $\mathrm{NO}_{2}$ or $\mathrm{PO}_{4}^{3-}-\mathrm{P}$ detected at Wami-Ruvu reference sites (Table 3).

Table 2. Mean \pm standard error mean (SEM) of biometric data in Pangani and Wami-Ruvu sites.

\begin{tabular}{|c|c|c|c|c|c|c|c|c|c|c|c|c|c|c|c|}
\hline & $\begin{array}{c}\text { Relat } \\
\text { TR }\end{array}$ & $\begin{array}{c}\% \\
\text { Baet }\end{array}$ & $\begin{array}{c}\% \\
\text { Ephem }\end{array}$ & $\begin{array}{c}\% \\
\text { Trico }\end{array}$ & $\begin{array}{c}\% \\
\text { Pleco }\end{array}$ & $\begin{array}{c}\% \\
\text { Odon }\end{array}$ & $\begin{array}{c}\% \\
\text { EPT }\end{array}$ & SDI & $\begin{array}{c}\text { \%Dom. } \\
\text { Taxa }\end{array}$ & $\begin{array}{c}\% \\
\text { Diptera }\end{array}$ & $\begin{array}{c}\text { H-FBI } \\
\text { Score }\end{array}$ & $\begin{array}{c}\% \\
\text { Oligoch }\end{array}$ & $\begin{array}{c}\% \\
\text { Chiron }\end{array}$ & $\begin{array}{c}\% \\
\text { Non-Ins }\end{array}$ & $\begin{array}{l}\text { B-IBI } \\
\text { Score }\end{array}$ \\
\hline \multicolumn{16}{|c|}{ PANGANI REFERENCE } \\
\hline Mean & 27.22 & 28.89 & 45.23 & 20.77 & 1.42 & 7.44 & 66.68 & 2.64 & 29.15 & 11.75 & 4.37 & 0.00 & 2.78 & 2.35 & 89.33 \\
\hline SEM & 0.88 & 1.85 & 1.86 & 2.68 & 0.77 & 0.64 & 1.94 & 0.05 & 1.70 & 1.42 & 0.09 & 0.00 & 0.85 & 0.61 & 0.80 \\
\hline \multicolumn{16}{|c|}{ PANGANI MONITORING } \\
\hline Mean & 22.43 & 11.55 & 20.84 & 3.08 & 0.00 & 8.63 & 24.45 & 2.26 & 35.05 & 40.58 & 5.31 & 0.88 & 24.86 & 4.27 & 57.83 \\
\hline SEM & 0.58 & 1.83 & 1.89 & 0.57 & 0.00 & 0.78 & 2.07 & 0.03 & 1.16 & 1.80 & 0.04 & 0.20 & 0.76 & 0.96 & 0.93 \\
\hline \multicolumn{16}{|c|}{ WAMI-RUVU REFERENCE } \\
\hline SEM & 0.59 & 1.68 & 2.16 & 1.40 & 0.63 & 0.73 & 2.22 & 0.03 & 1.40 & 1.22 & 0.08 & 0.00 & 0.50 & 0.62 & 1.15 \\
\hline \multicolumn{16}{|c|}{ WAMI-RUVU MONITORING } \\
\hline Mean & 25.5 & 6.6 & 19.2 & 10.6 & 0.4 & 14.9 & 30.3 & 2.7 & 19.9 & 29.9 & 5.0 & 0.2 & 18.4 & 3.1 & 68.57 \\
\hline SEM & 0.4 & 1.1 & 1.1 & 0.6 & 0.1 & 1.0 & 1.1 & 0.0 & 0.9 & 1.5 & 0.0 & 0.1 & 1.1 & 0.3 & 0.97 \\
\hline
\end{tabular}


Table 3. Mean \pm standard error mean (SEM) of environmental variables in the site categories of Pangani and Wami-Ruvu river basins.

\begin{tabular}{|c|c|c|c|c|c|c|c|c|c|c|c|c|c|c|}
\hline & $\begin{array}{c}\text { Temp } \\
{ }^{\circ} \mathrm{C}\end{array}$ & $\begin{array}{c}\mathrm{pH} \\
-\end{array}$ & $\begin{array}{c}\mathrm{DO} \\
\mathrm{mg} / \mathrm{L}\end{array}$ & $\begin{array}{l}\text { Turb } \\
\text { NTU }\end{array}$ & $\begin{array}{c}\text { TDS } \\
\mathrm{mg} / \mathrm{L}\end{array}$ & $\begin{array}{l}\text { Cond } \\
\mu S / \mathrm{cm}\end{array}$ & $\begin{array}{c}\mathrm{NO}_{3} \\
\mathrm{mg} / \mathrm{L}\end{array}$ & $\begin{array}{c}\mathrm{NO}_{2} \\
\mathrm{mg} / \mathrm{L}\end{array}$ & $\begin{array}{c}\mathrm{NH}_{4}-\mathrm{N} \\
\mathrm{mg} / \mathrm{L}\end{array}$ & $\begin{array}{c}\text { SRP } \\
\mathrm{mg} / \mathrm{L}\end{array}$ & $\begin{array}{c}\mathrm{K} \\
\mathrm{mg} / \mathrm{L}\end{array}$ & $\begin{array}{c}\mathrm{SO}_{4}^{2-} \\
\mathrm{mg} / \mathrm{L}\end{array}$ & $\begin{array}{l}\text { BOD } \\
\mathrm{mg} / \mathrm{L}\end{array}$ & $\begin{array}{l}\text { COD } \\
\mathrm{mg} / \mathrm{L}\end{array}$ \\
\hline \multicolumn{15}{|c|}{ PANGANI REFERENCE } \\
\hline Mean & 20.38 & 7.61 & 7.82 & 0.87 & 26.92 & 14.62 & 0.25 & 0.66 & 0.10 & 0.51 & 0.33 & 0.27 & 9.52 & 22.47 \\
\hline SEM & 0.18 & 0.12 & 0.08 & 0.15 & 2.51 & 2.18 & 0.05 & 0.11 & 0.03 & 0.06 & 0.05 & 0.05 & 1.08 & 2.53 \\
\hline \multicolumn{15}{|c|}{ PANGANI MONITORING } \\
\hline Mean & 23.64 & 7.80 & 6.97 & 7.37 & 1031.42 & 37.10 & 0.37 & 4.39 & 0.43 & 0.39 & 1.13 & 0.94 & 40.75 & 110.84 \\
\hline SEM & 0.47 & 0.10 & 0.20 & 1.51 & 239.95 & 2.83 & 0.04 & 0.91 & 0.05 & 0.04 & 0.55 & 0.19 & 5.79 & 18.44 \\
\hline \multicolumn{15}{|c|}{ WAMI-RUVU REFERENCE } \\
\hline Mean & 22.51 & 7.88 & 8.89 & 26.33 & 72.33 & 103.35 & 0.00 & 0.14 & 0.08 & 0.00 & 0.02 & 0.60 & 6.76 & 15.08 \\
\hline SEM & 0.60 & 0.09 & 0.79 & 11.29 & 35.53 & 58.09 & 0.00 & 0.05 & 0.04 & 0.00 & 0.00 & 0.40 & 2.16 & 3.89 \\
\hline \multicolumn{15}{|c|}{ WAMI-RUVU MONITORING } \\
\hline Mean & 24.39 & 8.14 & 5.97 & 35.23 & 651.19 & 808.33 & 0.38 & 2.67 & 1.23 & 0.38 & 0.79 & 22.29 & 38.55 & 82.80 \\
\hline SEM & 0.48 & 0.14 & 0.61 & 6.56 & 293.52 & 384.42 & 0.20 & 1.35 & 0.76 & 0.10 & 0.25 & 18.39 & 20.56 & 37.63 \\
\hline
\end{tabular}

\subsection{Differences between the Basins and Site Categories}

\subsubsection{Sites versus Biometric Data}

B-IBI score was also weighted toward reference sites (on right side) in ordination since by definition all reference sites have good water and/or habitat quality. Percentages of B-IBI score, EPT, Ephemeroptera, Trichoptera, Baetidae, and Plecoptera were weighted toward isolated reference sites on the right site of PCA ordination (Figure 1(a) \& Figure 1(b)). Basin in which highly impacted sites were found to have the worst metric scores had lost much of their capacity to support diversity of pollution sensitive taxa [29]. On the contrary, percentages of Oligochaeta, Chironomidae, Odonata, Diptera, Dominant Taxa, Non-Insecta and Relative Taxa Richness vectors pointed toward monitoring sites (on left side) in ordination for each basin. Graphically, the biometric data had clearly discriminated reference sites from monitoring sites at each basin and consequently demonstrated the differences in water quality and physical habitat between the site categories. The impacted sites are characterized by either absence of any sensitive taxa or presence of few if any; greater dominance of only a few taxa that are tolerant to pollution [30]. Complete absence of taxa at impacted sites may also be related to the differences of in-stream environmental degradation along rivers as a result of human activities i.e., agriculture, urbanization, and industrialization. However, total disappearances of pollution intolerant taxa from all disturbed sites and continuous presence of Ephemeropteran, Odonata, Diptera, and Trichoptera in all sampled sites; suggest their potential use as key indicators of water quality assessment for biomonitoring programmes. Pollution tolerant taxa(i.e., Chironomidae and midge larvae) may also be more effective indicators of increased stress, 
PCA Plot - Correlation - Wami-Ruvu sites versus Biometric data

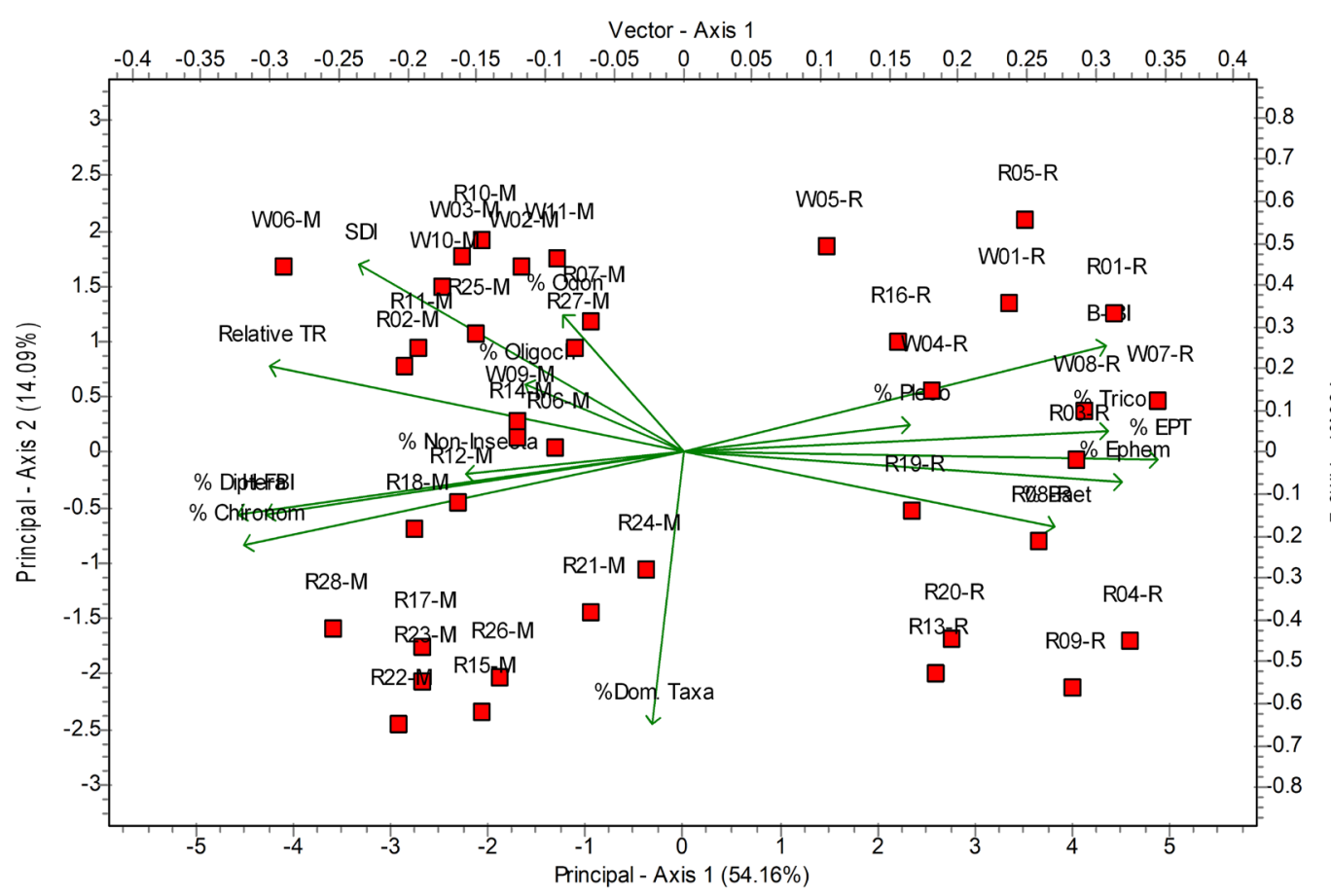

(a)

PCA Plot - Correlation - Pangani sites versus Biometric data

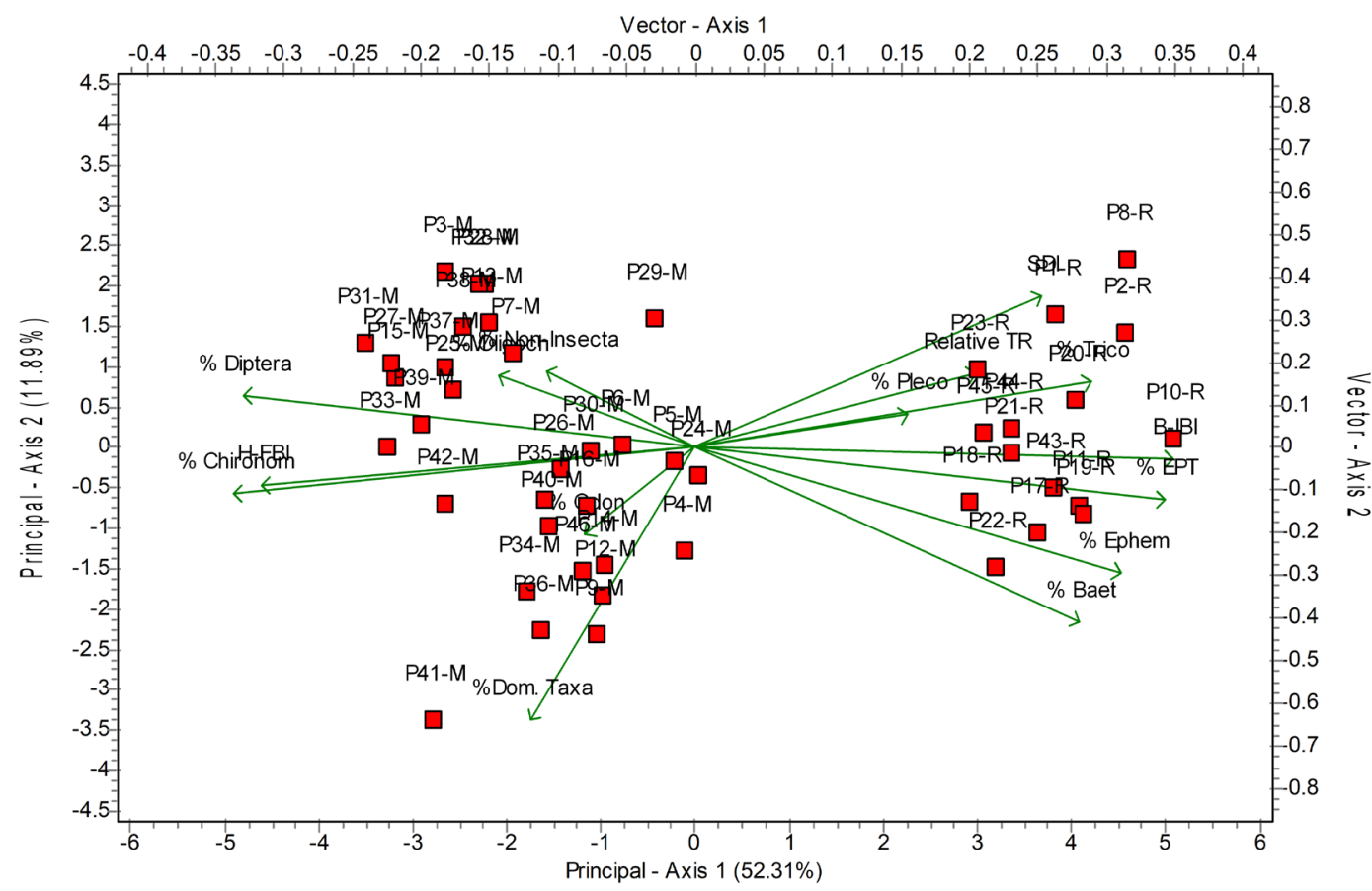

(b)

Key: \% stands for biometric data; Site codes with R (i.e., W01-R) referring Reference sites; and M (i.e., W03-M) referring the Monitoring sites.

Figure 1. (a) Principal Components Analysis (PCA) ordination showing two distinct patterns of biometrics along Wami-Ruvu site categories; (b) Principal Components Analysis (PCA) ordination showing two distinct patterns of biometrics along Pangani site categories. 
due to their high abundance in impacted sites compared to other families [31].

\subsubsection{Significant Tests on Differences between the Basins and Site Categories}

Seven of the 30 biometric and environmental variables tested were significantly differentiating the basins and site categories, with $\mathrm{p}$ values $<0.05$ (Table 4).

\subsubsection{Water Quality Status of the Basins}

The B-IBI score was used for this study as it combines several distinctive, stressinfluenced community characteristics into a single aggregate value that can be used to compare the level of stress evidenced by communities from different rivers localities. The B-IBI scores calculated from 14 biometric data resulted in categorization of sites based on their impairment levels with reference sites out-scoring monitoring sites at each basin. The scores indicated that $43.53 \%$ of the sampling sites

Table 4. One way ANOVA showing effectiveness of seven biotic and abiotic variables to discern the basins and site categories

\begin{tabular}{|c|c|c|c|c|}
\hline S/N. & Variable & Compared Classes & Probability & $\begin{array}{c}\text { Differences between } \\
\text { the classes }\end{array}$ \\
\hline \multirow[t]{3}{*}{1.} & B-IBI scores & Pr versus $W R r$ & $\mathrm{P}=0.0017$ & Very significant \\
\hline & & Pm versus $W R m$ & $\mathrm{P}<0.0001$ & Extremely significant \\
\hline & & $\mathrm{Pb}$ versus $\mathrm{WRb}$ & $\mathrm{F}_{(3,81)}=197.55 ; \mathrm{P}<0.05$ & Significant \\
\hline \multirow[t]{3}{*}{2.} & F-IBI scores & Pr versus $W R r$ & $\mathrm{P}=0.02$ & Significant \\
\hline & & Pm versus WRm & $\mathrm{P}=0.0002$ & Extremely significant \\
\hline & & $\mathrm{Pb}$ versus $\mathrm{WRb}$ & $\mathrm{F}_{(3,81)}=86.29 ; \mathrm{P}<0.05$ & Significant \\
\hline \multirow[t]{3}{*}{3.} & Turbidity & Pr versus WRr & $\mathrm{P}=0.038$ & Significant \\
\hline & & Pm versus $W R m$ & $\mathrm{P}=0.0007$ & Extremely significant \\
\hline & & $\mathrm{Pb}$ versus $\mathrm{WRb}$ & $\mathrm{F}_{(3,81)}=8.22 ; \mathrm{P}<0.05$ & Significant \\
\hline \multirow[t]{3}{*}{4.} & $\%$ SDI & Pr versus WRr & $P=0.013$ & Significant different \\
\hline & & Pm versus $W R m$ & $\mathrm{P}<0.0001$ & Extremely significant \\
\hline & & $P b$ versus $W R b$ & $\mathrm{~F}_{(3,81)}=30.34 ; \mathrm{P}=0.05$ & Significant \\
\hline \multirow[t]{3}{*}{5.} & $\%$ Odonata & Pr versus $\mathrm{WRr}$ & $\mathrm{P}=0.0036$ & Very significant \\
\hline & & Pm versus $W R m$ & $\mathrm{P}<0.0001$ & Extremely significant \\
\hline & & $\mathrm{Pb}$ versus $\mathrm{WRb}$ & $\mathrm{F}_{(3,81)}=15.92 ; \mathrm{P}<0.05$ & Significant \\
\hline \multirow[t]{3}{*}{6.} & $\%$ Dominant taxa & Pr versus WRr & $\mathrm{P}<0.0001$ & Extremely significant \\
\hline & & Pm versus $W R m$ & $\mathrm{P}<0.0001$ & Extremely significant \\
\hline & & $\mathrm{Pb}$ versus $\mathrm{WRb}$ & $\mathrm{F}_{(3,81)}=39.89 ; \mathrm{P}<0.05$ & Significant \\
\hline \multirow[t]{3}{*}{7.} & $\%$ Taxa richness & Pr versus WRr & $\mathrm{P}<0.0001$ & Extremely significant \\
\hline & & Pm versus $W R m$ & $P=0.001$ & Very significant \\
\hline & & $\mathrm{Pb}$ versus $\mathrm{WRb}$ & $\mathrm{F}_{(3,81)}=24.38 ; \mathrm{P}<0.05$ & Significant \\
\hline
\end{tabular}

Key: $\mathrm{Pb}=$ Pangani basin; $\mathrm{WRb}=\mathrm{Wami}-\mathrm{Ruvu}$ basin; $\mathrm{Pr}=$ Reference sites at Pangani; $\mathrm{WRr}=$ Reference site at Wami-Ruvu; $\mathrm{Pm}=$ Monitoring site at Pangani and WRm = Monitoring site at Wami-Ruvu. 
Table 5. Categorization of sites into different impairment levels based on B-IBI score results.

\begin{tabular}{|c|c|c|c|c|}
\hline $\begin{array}{l}\text { B-IBI } \\
\text { Scores }\end{array}$ & Water Quality & Impairment & Pangani Basin & Wami-Ruvu Basin \\
\hline $20-46$ & Very Poor to poor & Severe to Slight & - & - \\
\hline$>46-72$ & Fair to Good & $\begin{array}{l}\text { Moderate } \\
\text { to Less }\end{array}$ & $\begin{array}{c}\text { All } 31 \\
\text { monitoring sites }\end{array}$ & $\begin{array}{l}17 \text { monitoring sites (W06, } \\
\text { W09,W10, W11, R02, R11, R12, R14, } \\
\text { R16, R17, R18, R21, R22, R23, R24, } \\
\text { R26 and R28) }\end{array}$ \\
\hline$>72-100$ & $\begin{array}{l}\text { Very Good } \\
\text { to Excellent }\end{array}$ & $\begin{array}{l}\text { Very Little } \\
\text { to None }\end{array}$ & $\begin{array}{l}\text { All } 15 \\
\text { reference sites }\end{array}$ & $\begin{array}{c}\text { All } 15 \text { reference sites and } 7 \\
\text { monitoring sites (W02, W03, R06, } \\
\text { R07, R10, R25 and R27) }\end{array}$ \\
\hline
\end{tabular}

analyzed in the catchment basin presented very good water quality, $56.47 \%$ fair to good water quality (Table 5).

\section{Discussion}

Macro-invertebrate communities have become somewhat out of balance among site categories and the basins, both taxonomically and ecologically. Composition of macro-invertebrates and environmental variables were different not only between site categories and the basins but also presented seasonal variation. When comparing the taxonomic list of these two basins, macro-invertebrate organisms in Pangani seem to be more diverse and abundant. It was also possible to observe greater representativeness of some sensitive taxa like Coleoptera, and Ephemeroptera, and Trichoptera in all site categories of Pangani and Wami-Ruvu, respectively, which were not affiliated with high impacts. The results are in line with similar findings by Rosenberg and Resh [32], Bryne and Dates [33], Moog et al. [34], Compin and Céréghino [35], Morse et al. [36], Song et al. [37] and Foto Menbohan [38] who associated presence of coleopterans, ephemeropterans and trichopterans with good water quality and habitat suitability. The occurrence of these sensitive taxa in all site categories further suggests a possible improvement in the environmental conditions related to the decrease in concentrations of nutrients and changes in some of the physico-chemical parameters (e.g., dissolved oxygen, $\mathrm{pH}$, temperature and electrical conductivity), and hence, reflecting in the greater richness of macro-invertebrate assemblages.

Maximum values of water conductivity that reaches $(7854.20 \mu \mathrm{S} / \mathrm{cm})$, TDS (5838.70 mg/L), COD (928.01 mg/L), BOD $(500.80 \mathrm{mg} / \mathrm{L}), \mathrm{SO}_{4}^{2-} \quad(444.51 \mathrm{mg} / \mathrm{L})$ and turbidity (104.44 NTU) and depletion of DO from 16.97 to $0.58 \mathrm{mg} / \mathrm{L}$ were registered at Wami-Ruvu monitoring sites and could have been responsible for the absence of Nepidae, Notonectidae and Lumnichidae families. Indeed, the absence of these families in Wami-Ruvu basin is undoubtedly due to differences in hydrological patterns between Pangani and Wami-Ruvu basins and levels of impairment caused by the uncontrolled discharge of domestic sewages, agrochemical inputs and industrial wastes in the rivers [39] [40]. These results are consistent with those of Compin and Céréghino [35], Song et al. [37] and Foto Men- 
bohan [38] who showed that a decrease in Coleoptera richness (i.e., Lumnichidae family) in human impacted rivers is clearly related to changes in water quality and habitat suitability. It can therefore be hypothesized that these taxa would have historically been present at Wami-Ruvu before human disturbances, as most of the environmental variables i.e., TDS and DO were found with values above recommended limits of $500 \mathrm{mg} / \mathrm{L}$ and $5 \mathrm{mg} / \mathrm{L}$, respectively [41] [42]. Moreover, the results also agree with studies of Fuji [43] who reported the effect of environmental variables on the occurrence and distribution of macro-invertebrate organisms in freshwater ecosystem.

Statistical tests revealed a correlation of the metrics related to impacts with TDS, turbidity, COD, BOD, DO, temperature conductivity, potassium, sulphate, nitrogen, and phosphorus contents associated with improper land uses near basins [44] [45]. The two site categories of Pangani and Wami-Ruvu basins were clearly separated on PCA plot ordination, with two distinct patterns of biometrics that representing least and more pollution tolerant macro-invertebrate communities (Figure 1(a) \& Figure 1(b)). Although, sensitivities of macro-invertebrates to pollution do vary [46], increase or decrease of physico-chemical variables beyond required limits is considered harmful to least tolerant living biota [23] [46] [47] [48]. For instance, the increased in nutrients beyond required limits are likely to cause the reduced occurrences of intolerant taxa (trichopterans and plecopterans) and favour the tolerant taxa (dipterans i.e., Chironomidae), which can strive better in low oxygenated conditions [23] [49] [50]. However, the dominance does not always reflect better environment, as mild disturbance may favor some tolerant taxa with subsequent reduction in sensitive taxa.

Reference sites of the two basins were prominently located in riffles and undercut banks of stone substrates with subsequent waters of high DO and lower nutrient levels compared to fine substrate (gravel, sand and mud) of monitoring sites. These fine substrates contain loose sediments and decomposed organic matter of low DO, as a result, support only tolerant macro-invertebrate communities [51] compared to those accommodated by stone substrates. Heptageniidae and Baetidae (Ephemeroptera), Chironomidae (Diptera) and Hydropsychidae (Trichoptera) for example, can strive under serious environmental stresses with low DO waters because of their ability to oxidize mud on the river bottom and produce haemoglobin [50] [52] [53] [54]. Their diverse nature and ability to tolerate a wider range of tolerance towards varied environmental conditions might have contributed to their distribution. However, the dominance of dipterans (Chironomidae) in fine bottom substrates and Trichoptera and Ephemeroptera on riffles and hard substrate sites, which revealed in this study, is also consistent with previous taxonomical and ecological studies conducted by Lyimo [30], Elias et al. [55], and Kaaya [8] in some Tanzanian rivers. Contrary to Heptageniidae and Hydropsychidae, Plecoptera and Trichoptera were only found at the reference sites and were totally absent at monitoring sites (especially in dry season) because they have predilection for habitats of good water quality [56]. Moreover, Ephemeroptera, Plecoptera and Trichoptera were also reported by Morse et al. 
[36] as taxa that are very sensitive to pollutants i.e., nutrients, sediments, heavy metals, chemicals and organic nutrients.

Monitoring sites were dominated by pollution tolerant biometrics while intolerant biometrics dominated the reference sites despite the basins being located in different geo-hydrological pattern. Hilsenhoff Family-level Biotic Index (H-FBI) findings have also indicated the slightly enriched type of water quality in reference sites with monitoring sites demonstrating a deterioration from slightly enriched to enriched water quality (Table 2). The H-FBI results concur with B-IBI score in which reference sites were segregated from monitoring sites (Table 4). H-FBI and B-IBI scores have suggested the slight deterioration of water quality in monitoring sites compared to reference sites as a consequence of improper land use and habitat degradation [44] [45] [57] [58] [59]. Moreover, the dominance of intolerant taxa (Ephemeroptera and Trichoptera) in the reference sites as opposed to tolerant taxa (Diptera and Odonata) and absence or fewer Plecoptera in monitoring sites also corroborates findings from other studies Kasangaki et al. [60], Masese et al. [61] and Aura et al. [62] in tropical African rivers. Similarly, the observed fewer numbers of Plecoptera at Pangani $(0.25 \%, \mathrm{~N}=19)$ and Wami-Ruvu $(0.81 \%$, $\mathrm{N}=40$ ) are also in line with most other studies conducted in tropical African rivers [55] [60] [62] [63] [64] [65], as Perlidae $s p$ was rarely encountered and totally absent in severely degraded sites. In another sense, the dominance of certain taxa (i.e., Chironomidae and Naididae), and absence of the other (i.e., Plecoptera), at some sites can also be associated with habitat modification [8] [55] [66]. In summary, this provides further evidence to support the fact that, presence of human induced activities discharging various forms of pollutants especially nutrients into watersheds, can predict macro-invertebrates structure and function.

Therefore, more diverse orders with a wider range of occurrences and tolerance to pollution (Ephemeroptera (E), Diptera (D), Odonata (O) and Trichoptera $(\mathrm{T})$ ) can be considered potential bio-indicators in developing biomonitoring index for Tanzanian rivers as they showed a significant discriminating power that separated reference from monitoring sites.

\section{Conclusion}

With the aid of measured physico-chemical variables, all identified orders were useful in detecting disparities between site categories and basins at a family level. However, increasing their taxonomic resolution to genus or species levels might improve or enhance the ability to detect differences among site categories and the two basins with respect to their macro-invertebrate assemblages and environmental variables. Updated ecological inventory and the taxonomic list (including distribution records and descriptions of new taxa) generated from this study will contribute to new effort of documenting existing macro-invertebrate species and development of regional identification guides and cost-effective biomonitoring index. It was recognized that more diverse orders with wider range 
of occurrences and tolerance to pollution can be considered as bio-indicators in developing species level biomonitoring index for Tropical African Rivers as they had significant power of discriminating.

\section{Acknowledgements}

The author sends gratefully acknowledge COSTECH for the financial support, and Department of Aquatic Sciences and Fisheries for providing laboratory space and facilities to analyze water and macrobenthos samples.

\section{Conflicts of Interest}

The author declares no conflicts of interest regarding the publication of this paper.

\section{References}

[1] Karr, J.R. and Chu, E.W. (1999) Restoring Life in Running Waters: Better Biological Monitoring. Island Press, Washington DC, $206 \mathrm{p}$.

[2] Revenga, C. and Kura, Y. (2003) Status and Trends of Biodiversity of Inland Water Ecosystems. CBD Technical Series No. 11, Secretariat of the Convention on Biological Diversity, Montreal, $126 \mathrm{p}$.

[3] Ellison, A.M. (2004) Wetlands of Central America. Wetlands Ecology and Management, 12, 3-55. https://doi.org/10.1023/B:WETL.0000016809.95746.b1

[4] Benetti, C.J. and Garrido, J. (2010) The Influence of Stream Habitat and Water Quality on Water Beetles Assemblages in Two Rivers in Northwest Spain. Vie et Milieu, 60, 53-63.

[5] Jamil, K. (2001) Bioindicators and Biomarkers of Environmental Pollution and Risk Assessment. Science Publisher Inc., Enfield.

[6] Leveque, C. and Balian, E.V. (2005) Conservation of Freshwater Biodiversity: Does the Real World Meet Scientific Dreams? Hydrobiologia, 542, Article No. 23. https://doi.org/10.1007/s10750-005-0891-0

[7] Likens, G.E. (2010) Lake Ecosystem Ecology. Academic Press, San Diego, 463 p.

[8] Kaaya, L.T. (2015) Towards a Classification of Tanzanian Rivers: A Bioassessment and Ecological Management Tool. A Case Study of the Pangani, Rufiji and Wami-River Basins. African Journal of Aquatic Science, 40, 37-45. https://doi.org/10.2989/16085914.2015.1008970

[9] Patang, F., Soegianto, A. and Hariyanto, S. (2018) Benthic Macroinvertebrates Diversity as Bioindicator of Water Quality of Some Rivers in East Kalimantan, Indonesia. International Journal of Ecology, 2018, Article ID: 5129421. https://doi.org/10.1155/2018/5129421

[10] Sala, O.E., Chapin, F.S., Armesto, J.J., Berlow, R., Bloomfield, J., Dirzo, R., Huber-Sanwald, E., Huenneke, L.F., Jackson, R.B., Kinzig, A., Leemans, R., Lodge, D., Mooney, H.A., Oesterheld, M., Poff, N.L., Sykes, M.T., Walker, B.H., Walker, M. and Wall, D.H. (2000) Global Biodiversity Scenarios for the Year 2100. Science, 287, 1770-1774. https://doi.org/10.1126/science.287.5459.1770

[11] Hart, D.D. (1994) Building a Stronger Partnership between Ecological Research and Biological Monitoring. Journal of the North American Benthological Society, 13, 110-116. https://doi.org/10.2307/1467271 
[12] Zedler, J.B. and Kercher, S. (2005) Wetland Resources: Status, Trends, Ecosystem Services, and Restorability. Annual Review of Environment and Resources, 30, 39-74. https://doi.org/10.1146/annurev.energy.30.050504.144248

[13] Verhoeven, J.T.A., Arheimer, A., Yin, C. and Hefting, M.M. (2006) Regional and Global Concerns over Wetlands and Water Quality. Trends in Ecology and Evolution, 21, 96-103. https://doi.org/10.1016/j.tree.2005.11.015

[14] Ak'habuhaya, J. and Lodenius, M. (1988) Metal Pollution of River Msimbazi, Tanzania. Environment International, 14, 511-514.

[15] Mkuula, S. (1993) Pollution of Wetlands in Tanzania. Unpublished Report, National Environment Management Council, Dar es Salaam, 85 p.

[16] Ngana, J.O. (2001) Integrated Water Resources Management. The Case of the Pangani River Basin. In: Ngana, J.O., Ed., Water Resources Management in the Pangani river Basin: Challenges and Opportunities, Dar es Salaam University Press, Dar es Salaam, 1-8.

[17] American Public Health Association (1998) Standard Methods for the Examination of Water and Wastewater. 20th Edition, American Public Health Association, Washington DC.

[18] American Public Health Association (2000) Standard Methods for the Analysis of Water and Wastewater. 15th Edition, American Public Health Association and Water Pollution Control Federation, Washington DC, 12-56.

[19] Wetzel, R.G. and Linkens, G. (2013) Limnological Analyses. Springer (India) Publisher Private Ltd., New York, 429 p. https://doi.org/10.1007/978-1-4757-3250-4

[20] Barbour, C.D.M.T., Gerritsen, J., Snyder, B.D. and Stribling, J.B. (1999) Rapid Bioassessment Protocols for Use in Streams and Wadeable Rivers: Periphyton, Benthic Macro-Invertebrates and Fish. 2nd Edition, United State Environmental Protection Agency, Office of Water, Washington DC.

[21] Soedarso, J. and Wardiatno, Y. (2015) Assessment of the Quality Status of the River with Macrozoobenthos as Indicator. Pena Nusantara, Bogor.

[22] Merritt, R.W. and Cummins, K.W. (1996) An Introduction to the Aquatic Insects of North America. Kendall/Hunt Publishing Company, Dubuque, 862.

[23] Thorn, J.H. and Covich, A.P. (1991) Ecology and classification of North American Freshwater Invertebrates. Academic Press, San Diego, 1056 p.

[24] Hilsenhoff, W.L. (1988) Rapid Field Assessment of Organic Pollution with a Family Level Biotic Index. Journal of the North American Benthological Society, 7, 65-68. https://doi.org/10.2307/1467832

[25] Pond, G.J., Call, S.C., Brumley, J.F. and Compton, M.C. (2003) The Kentucky Macroinvertebrate Bioassessment Index: Derivation of Regional Narrative Criteria for Headwater and Wadeable Streams. Kentucky Department for Environmental Protection, Division of Water, Frankfort.

[26] Arslan, N., Salur, A., Kalyoncu, H., Mercan, D., Barisik, B. and Odabasi, D.A. (2016) The Use of BMWP and ASPT Indices for Evaluation of Water Quality According to Macroinvertebrates in Küçük Menderes River (Turkey). Biologia, 71, 49-57. https://doi.org/10.1515/biolog-2016-0005

[27] Seaby, R.M. and Henderson, P.A. (2006) Species Diversity and Richness Version 4. Pisces Conservation Ltd., Lymington, England.

[28] Seaby, R.M. and Henderson, P.A. (2006) Community Analysis Package Version 4. Pisces Conservation Ltd., Limington, 123.

[29] Akasaka, M., Takamura, N., Mitsuhashi, H. and Kadono, Y. (2010) Effects of Land 
Use on Aquatic Macrophyte Diversity and Water Quality of Ponds. Freshwater Biology, 55, 909-922. https://doi.org/10.1111/j.1365-2427.2009.02334.x

[30] Lyimo, E. (2012) Amphibian and Macro-Invertebrate Response towards Physical and Chemical Properties of Themi River, Arusha Tanzania. Master Thesis, Faculty of Applied Ecology and Agricultural Sciences, Hedmark University College, Elverum.

[31] Eggermont, H. and Verschuren, D. (2003) Impact of Soil Erosion in Disturbed Tributary Drainages on the Benthic Macroinvertebrate Fauna of Lake Tanganyika, East Africa. Biological Conservation, 113, 99-109.

[32] Rosenberg, D.M. and Resh, V.H. (1993) Freshwater Biomonitoring and Benthic Macroinvertebrates. Chapman \& Hall, New York.

[33] Bryne, J. and Dates, G. (1997) Living Waters, Using Benthic Macro-Invertebrates and Habit to Assess Your River's Health. River Watch Network. CRC Press, Boca Raton.

[34] Moog, O., Bauernfeind, E. and Weichselbaumer, P. (1995) The use of Ephemeroptera as Saprobic Indicators in Austria. Proceedings of 8 th International Conference on Ephemeroptera, Lausanne, 14-20 August 1995, 254-260.

[35] Cereghino, R., Park, Y., Compin, A. and Lek, S. (2003) Predicting the Species Richness of Aquatic Insects in Streams Using a Limited Number of Environmental Variables. Journal of the North American Benthological Society, 22, 442-456. https://doi.org/10.2307/1468273

[36] Morse, J.C., Bae, Y.J., Munkhjarkal, G., Sangpradub, N., Tanda, K., Tatyana, S.V., Wang, B., Yang, L. and Yule, C.M., 2007. Freshwater Bio-MONITORING with Macro-Invertebrates in East Asia. Frontiers in Ecology and the Environment, 5, 33-42. https://doi.org/10.1890/1540-9295(2007)5[33:FBWMIE]2.0.CO;2

[37] Song, M.Y., Leprieur, F., Thomas, A., Lek-Ang, S., Chon, T.S. and Lek, S. (2009) Impact of Agricultural Land Use on Aquatic Insect Assemblages in the Garonne river Catchment (SW France). Aquatic Ecology, 43, 999-1009. https://doi.org/10.1007/s10452-008-9218-3

[38] Foto Menbohan, S. (2012) Bio-Ecology of Epilithic Diatoms in the Mfoundi River: Diversity, Spatial Distribution and Influence of Organic Pollution. Journal of Water Science, 25, 203-218. https://doi.org/10.7202/1013103ar

[39] Rinne, J.N. (1988) Effects of Livestock Grazing on Aquatic Invertebrates in Montanestream, New Mexico. The Great Basin Naturalist, 48, 146-153.

[40] Morris, C.C., Jawyer, J.A., Bennet, H.H. and Robinson, C.D. (2003) Effects of Sediment Quality on the Health of Aquatic Ecosystem: A Case Study of Depth of Fines in Coastal Plain Streams in Alabama. In: Simon, T.P., Ed., Biological Response Signatures. Indicator Patterns Using Aquatic Communities, CRC Press, Boca Raton, 113-120.

[41] Chapman, L.J., Schneider, K.R., Apodaca, C. and Chapman, C.A. (1996) Respiratory ecology of macro-invertebrates in a swamp river system of East Africa. Biotropica, 36, 572-585. https://doi.org/10.1646/1598

[42] World Health Organization (2009) Guidelines for Drinking Water Quality. World Health Organization, Geneva.

[43] Fuji, T. (2007) Spatial Patterns of Benthic Macrofauna in Relation to Environmental Variables in an Intertidal Habitat in the Humber Estuary, UK: Developing a Tool for Estuarine Shoreline Management. Estuarine, Coastal and Shelf Science, 75, 101-119.

[44] Kidan, W.G. (2010) Biodiversity Assessment: Major Vegetation and Land Use Impacts of Enfranz Riverine Wetland in Lake Tana Watershed, Northern Bahir Dar, 
Ethiopia. Unpublished Thesis for Award of MSc Degree, Bahir Dar University, Bahir Dar, 104 p.

[45] Masese, F.O., Omukoto, J.O. and Nyakeya, K. (2013) Biomonitoring as a Prerequisite for Sustainable Water Resources: A Review of Status, Opportunities and Challenges to Scaling up in East Africa. Ecohydrology and Hydrobiology, 13, 173-191.

[46] Yuan, L.L. (2004) Assigning Macroinvertebrate Tolerance Classifications Using Generalized Additive Models. Freshwater Biology, 49, 662-677. https://doi.org/10.1111/j.1365-2427.2004.01206.x

[47] Kimmel, W.G. (1983) The Impact of Acid Mine Drainage on the Stream Ecosystem. In: Majumdar, S.K. and Miller, W.W., Eds, Pennsylvania Coal: Resources, Technology and Utilization, Pennsylvania Academy of Science, Pennsylvania, 424-437.

[48] Angelier, E. (2003) Ecology of Streams and Rivers. Science Publishers Inc., Enfield, $215 \mathrm{p}$.

[49] Lake, P.S. (2003) Ecological Effects of Perturbation by Drought in Flowing Waters. Freshwater Biology, 48, 1161-1172. https://doi.org/10.1046/j.1365-2427.2003.01086.x

[50] Elias, J.D., Ijumba, J.N. and Mamboya, F.A. (2014) Effectiveness and Compatibility of Non-Tropical Bio-Monitoring Indices for Assessing Pollution in Tropical Rivers-A Review. International Journal of Ecosystem, 4, 128-134.

[51] Koel, T.M. and Stevenson, K.E. (2002) Effects of Dredged Material Placement on Benthic Macroinvertebrates of the Illinois River. Hydrobiologia, 474, 229-238. https://doi.org/10.1023/A:1016500324467

[52] Simic, V. and Simić, S. (1999) Use of River Macro-Invertebrates of a Serbia River to formulate a Biotic Index. Hydrobiologia, 416, 51-64.

https://doi.org/10.1023/A:1003864610386

[53] Paunovic, M., Simic, V., Simonovic, P., Cvijan, M., Subakov, G., Simic, S., Stojanovic, B., Petrovic, A. and Gacic, Z. (2007) Biological Quality Elements in WFD Implementation in Serbia-Typology Reference Conditions and Ecological Status Class Boundaries.

[54] Enkhtaivan, S. and Soldán, T. (2004) Mayflies of the Lake Hovsgol Region, Mongolia. In: Hauer, F.R., Stanford, J.A. and Newell, R.L., Eds., 2004 International Joint Meeting, XI International Conference on Ephemeroptera, XV International Symposium on Plecoptera, University of California publications, Montana, 103-115. [Google Scholar] https://doi.org/10.1525/california/9780520098688.003.0008

[55] Elias, J.D., Ijumba, J.N., Mgaya, Y.D. and Mamboya, F. (2014) Study on Freshwater Macroinvertebrates of Some Tanzanian Rivers as a Basis for Developing Biomonitoring Index for Assessing Pollution in Tropical African Regions. Journal of Ecosystems, 2014, Article ID: 985389. https://doi.org/10.1155/2014/985389

[56] Richards, C., Havo, R.J., Johnson, L.B. and Host, G.E. (1997) Catchment and Reach Scale Properties as Indicated of Macro-Invertebrates Species Traits. Freshwater Biology, 37, 219-230. https://doi.org/10.1046/j.1365-2427.1997.d01-540.x

[57] Salomoni, S.E., Ocha, O.R. and Eite, E.H.L. (2007) Limnological Characterization of Gravataí River, Rio Grande do Sul. Acta Limnologica Brasiliensia, 19, 1-14.

[58] Bahar, M. D. M., Ohmori, H. and Yamamuro, M. (2008) Relationship between River Water Quality and Land Use in a Small River Basin Running through the Urbanizing Area of Central Japan. Limnology, 9, 19-26.

https://doi.org/10.1007/s10201-007-0227-Z

[59] Abrehet, K.M., Wondie, A., Mingist, M. and Vijverberg, J. (2014) Spatial and Sea- 
sonal Variation in the Macro-Invertebrates and Physico-Chemical Parameters of the Enfranz River, Lake Tana Sub-Basin (Ethiopia). Ecohydrology and Hydrobiology, 14, 304-312.

[60] Kasangaki, A., Chapman, L. J. and Balirwa, J. (2008) Land Use and the Ecology of Benthic Macroinvertebrate Assemblages of High-Altitude Rainforest Streams in Uganda. Freshwater Biology, 53, 681-697. https://doi.org/10.1111/j.1365-2427.2007.01925.x

[61] Masese, F.O, Muchiri, M. and Raburu, P.O. (2010) A Preliminary Benthic Macroinvertebrate Index of Biotic Integrity (B-IBI) for Monitoring the Moiben River, Lake Victoria, Kenya. African Journal of Aquatic Science, 34, 1-14. https://doi.org/10.2989/AJAS.2009.34.1.1.726

[62] Aura, C.M., Raburu, P.O. and Herman, J. (2010) A Preliminary Macroinvertebrate Index of Biotic Integrity for Bioassessment of the Kipkaren and Sosiani Rivers, Nzoia River basin, Kenya. Lakes \& Reservoirs. Science, Policy and Management for Sustainable Use, 15, 119-128. https://doi.org/10.1111/j.1440-1770.2010.00432.x

[63] Ndaruga, A.M, Ndiritu, G.G, Gichuki, N.N. and Wamich, W.N. (2004) Impact of Water Quality on Macroinvertebrate Assemblages along Tropical Stream in Kenya. African Journal of Ecology, 42, 208-216. https://doi.org/10.1111/j.1365-2028.2004.00516.x

[64] Sitotaw, B. (2006) Assessment of Benthic Macroinvertebrate Structures in Relation to Environmental Degradation in Some Ethiopian Rivers. Unpublished Thesis for Award of MSc Degree, University of Addis Ababa, Addis Ababa, 127 p.

[65] Kibichii, S., Shivoga, W.A., Muchiri, M. and Miller, S.N. (2007) Macroinvertebrate Assemblages along a Land-Use Gradient in the Upper River Njoro Watershed of Lake Nakuru Drainage Basin, Kenya. Lakes and Reservoirs: Research and Management, 12, 107-117. https://doi.org/10.1111/j.1440-1770.2007.00323.x

[66] Oscoz, J., Leunda, P.M., Miranda, R. and Escala, M.C. (2006) Summer Feeding Relationships of the Co-Occurring Phoxinus phoxinus and Gobio lozanoi (Cyprinidae) in an Iberian River. Folia Zoologica, 55, 418-432. 